\title{
Advances in Development of New Treatment for Leishmaniasis
}

\author{
Juliana Perrone Bezerra de Menezes, \\ Carlos Eduardo Sampaio Guedes, Antônio Luis de Oliveira Almeida Petersen, \\ Deborah Bittencourt Mothé Fraga, and Patrícia Sampaio Tavares Veras
}

\author{
Laboratório de Patologia e Biointervenção, CPqGM, FIOCRUZ, Rua Waldemar Falcão 121, Candeal, 40296-710 Salvador, BA, Brazil \\ Correspondence should be addressed to Patrícia Sampaio Tavares Veras; pveras@bahia.fiocruz.br
}

Received 16 December 2014; Revised 7 April 2015; Accepted 18 April 2015

Academic Editor: Harry P. De Koning

Copyright (C) 2015 Juliana Perrone Bezerra de Menezes et al. This is an open access article distributed under the Creative Commons Attribution License, which permits unrestricted use, distribution, and reproduction in any medium, provided the original work is properly cited.

\begin{abstract}
Leishmaniasis is a neglected infectious disease caused by several different species of protozoan parasites of the genus Leishmania. Current strategies to control this disease are mainly based on chemotherapy. Despite being available for the last 70 years, leishmanial chemotherapy has lack of efficiency, since its route of administration is difficult and it can cause serious side effects, which results in the emergence of resistant cases. The medical-scientific community is facing difficulties to overcome these problems with new suitable and efficient drugs, as well as the identification of new drug targets. The availability of the complete genome sequence of Leishmania has given the scientific community the possibility of large-scale analysis, which may lead to better understanding of parasite biology and consequent identification of novel drug targets. In this review we focus on how high-throughput analysis is helping us and other groups to identify novel targets for chemotherapeutic interventions. We further discuss recent data produced by our group regarding the use of the high-throughput techniques and how this helped us to identify and assess the potential of new identified targets.
\end{abstract}

\section{Leishmaniasis Treatment}

The World Health Organization (WHO) considers leishmaniasis to be one of the main neglected diseases in the world, affecting primarily the poor population of underdeveloped and developing countries [1]. Infection by parasites of the genus Leishmania causes a broad spectrum of clinical manifestations including subclinical (inapparent), localized (skin lesions), and disseminated infections (cutaneous, mucosal, or visceral) [2-5].

Tropical diseases, which are globally disperse and of great social-economic impact, affect mostly poor people in developing countries. Therefore, commercial interest in developing new pharmaceutical compounds $[6,7]$ for these diseases is limited because their treatment needs to be affordable to ensure access by the affected poor population. In addition, the advances in our understanding of the biology of Leishmania spp. have not translated into effective new chemotherapeutic compounds [8].
Recently, few alternative drugs have emerged for the treatment of leishmaniasis (Tables 1 and 2). None of the available drugs can be considered ideal due to their high toxicity, long duration of treatment, and severe adverse reactions, which often lead to treatment abandonment. In addition, the most commonly used drugs do not eliminate the parasites completely from all infected individuals $[9,10]$.

Pentavalent antimonials are the most frequently used drugs for the treatment of leishmaniasis, despite their variable effectiveness for both visceral and cutaneous leishmaniasis $[1,11-14]$. Due to accumulation in the tissues, antimonials can cause serious adverse effects, such as vomiting, nausea, anorexia, myalgia, abdominal pain, headache, arthralgia, and lethargy and can rarely cause the severe reaction of fatal cardiac arrhythmia $[1,12,15-18]$. These adverse effects are due to severe cardiotoxicity, pancreatitis, and nephrotoxicity that can require hospitalization and close monitoring of patients $[10,13]$. Efforts to reduce the toxicity of these drugs have not been effective [19]. The adverse effects and the lengthy 
TABLE 1: Drugs used for the treatment of leishmaniasis.

\begin{tabular}{|c|c|c|c|c|}
\hline Drugs & $\begin{array}{l}\text { Administration } \\
\text { route }\end{array}$ & Dosage & Efficacy & Toxicity \\
\hline $\begin{array}{l}\text { Pentavalent } \\
\text { antimonials } \\
{[1,10-20]}\end{array}$ & IM, IV, or IL & $20 \mathrm{mg} / \mathrm{kg} /$ day (28-30 days) & $\begin{array}{l}35-95 \% \\
\text { (depending on area) }\end{array}$ & $\begin{array}{l}\text { Severe cardiotoxicity, pancreatitis, } \\
\text { nephrotoxicity, hepatotoxicity }\end{array}$ \\
\hline $\begin{array}{l}\text { Amphotericin B } \\
{[1,15,16,21-23,40]}\end{array}$ & IV & $\begin{array}{l}0.75-1 \mathrm{mg} / \mathrm{kg} / \text { day }(15-20 \\
\text { days, daily or alternately) }\end{array}$ & $>90 \%$ & $\begin{array}{l}\text { Severe nephrotoxicity, infusion-related } \\
\text { reactions, hypokalemia, high fever }\end{array}$ \\
\hline $\begin{array}{l}\text { Liposomal } \\
\text { amphotericin B } \\
{[22,23,55-58]}\end{array}$ & IV & $\begin{array}{l}10-30 \mathrm{mg} / \mathrm{kg} \text { total dose } \\
\text { (single dose } \\
3-5 \mathrm{mg} / \mathrm{kg} / \text { dose) }\end{array}$ & $>97 \%$ & $\begin{array}{l}\text { Mild rigors and chills during infusion } \\
\text { Mild nephrotoxicity (infrequent and } \\
\text { mild) }\end{array}$ \\
\hline $\begin{array}{l}\text { Miltefosine } \\
{[1,16,30-} \\
32,45,48,49] \\
\end{array}$ & Oral & $100-150 \mathrm{mg} /$ day (28 days) & $\begin{array}{l}\text { Asia: } 94 \% \text { (India); } \\
\text { Africa: } 60 \%-93 \%\end{array}$ & $\begin{array}{l}\text { Vomiting and diarrhoea, nephrotoxicity, } \\
\text { hepatotoxicity, teratogenicity }\end{array}$ \\
\hline $\begin{array}{l}\text { Paromomycin } \\
{[1,27-29,45]}\end{array}$ & $\begin{array}{l}\text { IM }(\mathrm{VL}) \text { or } \\
\text { topic }(\mathrm{CL})\end{array}$ & $\begin{array}{l}15 \mathrm{mg} / \text { day (21 days) or } \\
20 \mathrm{mg} / \mathrm{kg} \text { (17 days) }\end{array}$ & $\begin{array}{l}94 \% \text { (India) } 46-85 \% \\
\text { (Africa) }\end{array}$ & $\begin{array}{l}\text { Severe nephrotoxicity, ototoxicity, } \\
\text { hepatotoxicity }\end{array}$ \\
\hline $\begin{array}{l}\text { Pentamidine } \\
{[1,16,20,24-26]}\end{array}$ & IM & $\begin{array}{l}3 \mathrm{mg} / \mathrm{kg} / \text { day IM every other } \\
\text { day for } 4 \text { injections }\end{array}$ & $\begin{array}{l}\text { 35-96\% (depending on } \\
\text { Leishmania species) }\end{array}$ & $\begin{array}{l}\text { High rate of hyperglycemia, as a result of } \\
\text { pancreatic damage; hypotension, } \\
\text { tachycardia, and electrocardiographic } \\
\text { changes }\end{array}$ \\
\hline
\end{tabular}

IV: intravenous administration; IM: intramuscular administration; IL: intralymphatic administration.

TABLE 2: Advantages and disadvantages of drugs used for the treatment of leishmaniasis.

\begin{tabular}{|c|c|c|c|c|c|}
\hline Drugs & Advantages & Disadvantages & Resistance & Price & Comment \\
\hline $\begin{array}{l}\text { Pentavalent } \\
\text { antimonials } \\
{[1,10-20]}\end{array}$ & $\begin{array}{l}\text { Easily } \\
\text { availability } \\
\text { and low cost }\end{array}$ & $\begin{array}{l}\text { Quality control; length of } \\
\text { treatment; painful } \\
\text { injection; toxicity; } \\
\text { resistance in India }\end{array}$ & $\begin{array}{l}\text { Common } \\
\text { (>65\% in Bihar, } \\
\text { India) }\end{array}$ & $\$ 50-198$ & $\begin{array}{l}\text { First line drugs but with high } \\
\text { incidences of resistance; variable } \\
\text { response in different species that } \\
\text { cause CL }\end{array}$ \\
\hline $\begin{array}{l}\text { Amphotericin B } \\
{[1,15,16,21-23,40]}\end{array}$ & $\begin{array}{l}\text { Primary } \\
\text { resistance is } \\
\text { unknown }\end{array}$ & $\begin{array}{l}\text { Need for slow intravenous } \\
\text { infusion; dose-limiting } \\
\text { nephrotoxicity; heat } \\
\text { instability }\end{array}$ & $\begin{array}{l}\text { Laboratory } \\
\text { strains }\end{array}$ & $\sim \$ 21-100$ & $\begin{array}{l}\text { Severe toxicity; need for prolonged } \\
\text { hospitalization; first-line drug for } \\
\text { VL in India, where there is } \\
\text { antimonial resistance }\end{array}$ \\
\hline $\begin{array}{l}\text { Liposomal } \\
\text { amphotericin B } \\
{[22,23,55-58]}\end{array}$ & $\begin{array}{l}\text { Highly } \\
\text { effective; low } \\
\text { toxicity }\end{array}$ & $\begin{array}{l}\text { Price; need for slow } \\
\text { intravenous infusion; heat } \\
\text { stability (needs to be stored } \\
\text { below } 25^{\circ} \mathrm{C} \text { ) }\end{array}$ & $\begin{array}{l}\text { Not } \\
\text { documented }\end{array}$ & $\$ 280-3000$ & High cost \\
\hline $\begin{array}{l}\text { Miltefosine } \\
{[1,16,30-} \\
32,45,48,49]\end{array}$ & $\begin{array}{l}\text { Effective and } \\
\text { safe }\end{array}$ & $\begin{array}{l}\text { Price; possibly teratogenic; } \\
\text { potential for resistance } \\
\text { (half-life); poor patient } \\
\text { compliance }\end{array}$ & $\begin{array}{l}\text { Laboratory } \\
\text { strains }\end{array}$ & $\$ 70-150$ & $\begin{array}{l}\text { Effective orally but its long half-life } \\
\text { may encourage emergence of } \\
\text { resistance on prolonged use; } \\
\text { effective for VL and against some } \\
\text { species that cause CL; } \\
\text { contraindicated in pregnancy as } \\
\text { found to be teratogenic in rats }\end{array}$ \\
\hline $\begin{array}{l}\text { Paromomycin } \\
{[1,27-29,45]}\end{array}$ & $\begin{array}{l}\text { Effective, well } \\
\text { tolerated, and } \\
\text { relatively } \\
\text { cheap }\end{array}$ & $\begin{array}{l}\text { Efficacy varies between and } \\
\text { within regions; potential } \\
\text { for resistance }\end{array}$ & $\begin{array}{l}\text { Laboratory } \\
\text { strains }\end{array}$ & $\$ 10-15$ & $\begin{array}{l}\text { Low cost; lack of efficacy in East } \\
\text { Africa; topical formulation available } \\
\text { for CL }\end{array}$ \\
\hline $\begin{array}{l}\text { Pentamidine } \\
{[1,16,20,24-26]}\end{array}$ & $\begin{array}{l}\text { Short-time } \\
\text { course }\end{array}$ & $\begin{array}{l}\text { Efficacy varies between } \\
\text { Leishmania species }\end{array}$ & $\begin{array}{l}\text { Not } \\
\text { documented }\end{array}$ & - & $\begin{array}{l}\text { For specific forms of CL in South } \\
\text { America only; first line of treatment } \\
\text { of CL in French Guiana }\end{array}$ \\
\hline
\end{tabular}

treatment period lead to treatment noncompliance and abandonment, favoring the emergence of resistant Leishmania strains, as in Bihar (India) [20].

Despite its high toxicity, amphotericin B is one of the first-line drugs for leishmaniasis treatment [21, 22]. Its intravenous administration frequently causes rigor, chills, and fever, associated with myocarditis and nephrotoxicity $[1,15,16]$. Amphotericin B formulations (the lipid complex, colloidal form, and the liposomal form) were developed to reduce adverse effects and improve pharmacokinetics and bioavailability. Although proven less toxic, these alternative formulations of amphotericin B have limitations for use in 
developing countries: they are very costly and unstable at higher temperatures (requiring cooling) [22, 23].

Pentamidine, another drug currently used for leishmaniasis treatment, is highly toxic and triggers important adverse effects, such as diabetes mellitus, severe hypoglycemia, hypotension, myocarditis, and renal toxicity and can ultimately cause death $[1,24]$. This drug is currently used infrequently due to the appearance of resistance cases [25], its high toxicity, and low efficacy [26]. Currently, pentamidine is mainly recommended when used in combined therapeutic protocols $[16,20]$.

Paromomycin is an alternative drug for leishmaniasis treatment [1]; however, parenteral formulations can cause serious adverse reactions, including nephrotoxicity and ototoxicity and more rarely hepatotoxicity [27-29]. Mitelfosine, an alternative antileishmanial drug $[1,30,31]$, has the advantage of oral administration. However, its use is limited for pregnant women, since the most severe side effects of this drug are the induction of teratogenesis and the occurrence of a high index of treatment failure [22,32]. In the last 35 years, many compounds have been found to have low efficacy against leishmaniasis, including rifampicin, tamoxifen, doxycycline, monomycine, trimethoprim, and nifurtimox $[16,21$, 24, 33-44].

Regarding selective antileishmanial activity, pentavalent antimonials can act against different species of Leishmania, whereas pentamidine has limited activity against specific Leishmania species [40]. Paromomycin [45] can be used topically to treat localized leishmaniasis caused by L. braziliensis, but not for that caused by other species of Leishmania $[46,47]$. Miltefosine, which is effective for the treatment of visceral leishmaniasis caused by $L$. donovani, seems to be ineffective in the treatment of infection by $L$. major and $L$. braziliensis [45]. Because many current antileishmanial drugs have only species-specific activity, new drugs or protocols should be scrutinized to determine their activity for the entire spectrum of Leishmania species and diseases.

Alternative protocols, such as the rational combination of drugs, have favorably reduced individual doses, treatment duration, and adverse effects [22]. In addition, these protocols provide a short-term solution by reducing costs, the frequency of treatment failure, and the occurrence of drug resistance [40, 48]. Seifert and Croft [49] evaluated a combination of antileishmanial drugs as an alternative to be used in place of pentavalent antimonials in cases of visceral leishmaniasis resistant to these drugs. The combination of miltefosine with amphotericin B or paromomycin was very efficient and could be helpful to treat antimony-resistant VL infections. Sundar and collaborators [48] compared the efficacy and safety of the treatment combining three antileishmanial drugs (amphotericin B in liposomal formulation, miltefosine, and paromomycin), to those of monotherapy with amphotericin $B$ in a study conducted in India. Although the efficacy of this multidrug regimen was similar to the monotherapy, the authors observed less frequent adverse effects, less severe disease, and shorter duration of the treatment with the multidrug regimen. Phase 3 studies have also been conducted in Asia and Africa to investigate the effectiveness of multidrug treatment protocols for visceral leishmaniasis.
Whether combination therapy will delay resistance, and how this is best achieved, will only be known from long-term studies [10]. In addition, combinations of immunotherapy and antileishmanial drugs have been investigated in the last 10 years $[10,50,51]$, showing variable efficacy.

Another approach for alternative treatment of leishmaniasis is the use of controlled release systems, such as liposomes and nanoparticles. This type of systems provides a greater efficacy and safety once drugs are adsorbed or encapsulated in carriers, reducing the dose and adverse reactions of conventional formulations [52-54]. A liposomal formulation of amphotericin B, Ambisome, has been used to treat leishmaniasis, showing better results than that obtained using the sodium stibogluconate. It produced fewer adverse reactions and treatment failures in patients with cutaneous leishmaniasis $[55,56]$. Ambisome has been used to treat HIV-Leishmania coinfected patients; however, this treatment did not reduce relapse and mortality rates for these coinfected patients, compared to those rates in HIV negative Leishmania-infected patients [57]. Similar results were described by Ritmeijer et al. [58] in a study conducted in Ethiopia. The stearylamine liposome formulation containing sodium stibogluconate developed by Roychoudhury et al. [59] showed efficacy against strains of $L$. donovani resistant to sodium stibogluconate. Shio et al. [60] revealed that another drug, oleylphosphocholine (OlPC), formulated as liposomes, killed intracellular amastigotes of L. major and L. mexicana in macrophages. Using a tattoo machine, they injected this formulation directly into the cutaneous lesions of infected $\mathrm{BALB} / \mathrm{c}$ mice, resulting in a complete regression of the skin lesions. However, further studies are needed to evaluate this new treatment approach.

Functionalized carbon nanotubes also have been tested as drug carriers against leishmaniasis. Amphotericin B attached to functionalized carbon nanotubes has a significantly greater leishmanicidal activity than conventional amphotericin B in L. donovani-infected hamsters [61]. Similarly, the attachment of betulin, a pentacyclic triterpenoid, to functionalized carbon nanotubes improved its leishmanicidal effect, with lower toxicity [62]. Recently, Ribeiro et al. [63] showed that amphotericin B conjugated to nanoparticles composed of chitosan-chondroitin sulfate had less cellular toxicity than conventional amphotericin B formulation and was more prone to kill Leishmania parasites inside parasitophorous vacuoles. To address the efficacy of these new antileishmanial formulations, additional in vivo studies should be conducted.

Another strategy to improve antileishmanial treatment is the identification of new targets both in parasites and in host cells. New potential targets for drugs have been identified in molecular and biochemical studies and some have been validated [64-66]. Studies to better understand the biology of host-parasite interactions would facilitate the design of more effective drugs against Leishmania infection. High performance techniques are currently being employed to identify particular parasite and host cell expressed molecules that can be finally used as chemotherapeutic targets [64-66]. Indeed, transcriptomics and proteomics have been important large-scale tools for understanding the biology of Leishmania 
and host interaction, favoring the identification of new targets for leishmaniasis treatment $[67,68]$.

\section{High-Throughput Screening for New Targets}

The robustness of critical cellular metabolism relies on a complex and highly linked adjustable network with redundant or alternative pathways to maintain the usual flow of molecules and materials in the cell [83]. Therefore, targeting parasite and host cell pathways, selected using high-throughput analyses, appears more promising than focusing on a specific enzyme or other individual molecules [84]. The use of a targetbased drug discovery approach that inhibits an individual target molecule would seldom generate the desired outcome. On the other hand, if a critical pathway is the target, then chemical compounds that interfere in this pathway could be selected. Apparently, studies of complex living systems should recognize with the limitations of more simple systems to develop effective and safe drugs to control diseases [85]. Therefore, consideration of the complexity of large-scale data that is central to drug discovery and development in the postgenomic era is a difficult undertaking [84]. Recently, these complex technologies have emerged as important tools for understanding the mechanisms of disease establishment, resistance to pathogens [86-88], and searching for new drug targets [84].

The massive increase in genomic data for pathogens that cause tropical diseases, in particular the completion of their genome sequence, has provided the opportunity to identify novel vaccine and chemotherapeutic targets. The development of functional genomics tools, such as microarray and more recently deep sequencing technology, as well as proteomics, has revealed strategies to achieve clinical goals [89]. In addition, these advances allowed the emergence of bioinformatics in the postgenomic era that enormously hastened the research process. Furthermore, computational algorithms and multiple confirmatory assay formats combined with high-throughput screening methodologies greatly contribute to the identification and characterization of novel potent drug targets [67]. Among largescale strategies, transcriptomic profiling and proteomics have emerged as potential approaches to these final goals [67]. Proteomics in addition to the transcriptomics approach, performed in several laboratories, have identified numerous stage-specific genes in Leishmania spp. [90-96], as well as primary resistance mechanisms and novel parasite targets [95, 97-99]. Between these two approaches, proteomics has proven more advantageous than microarray for the discovery of new therapeutic strategies in diseases caused by pathogens (Table 3) [69-82]. In particular, for trypanosomatids, proteomics has been preferred, because mRNA has been found to correlate poorly with protein species derived from the same gene [89].

Proteomics is being widely employed to study Leishmania and, in association with the annotated sequenced genome of Leishmania, seems a valuable strategy for dissection of both protein expression/regulation and function. Expression proteomics exploits the differential expression of leishmanial proteins as biomarkers for early diagnosis [100]. Furthermore, immunoproteomics efforts focused on evaluating responses to defined parasite $\mathrm{T}$-cell epitopes as vaccine/diagnostic targets. These approaches have also expanded the understanding of the array of events involved in Leishmania infection $[86,87]$. The construction of an index map for a large number of Leishmania species is another large-scale approach that was exploited by several authors and contributed to a better understanding of the biology of this parasite, aiming to identify and locate as many parasite proteins as possible [21, 101]. Microarray technology has also been used successfully to identify critical genes expressed during the development and differentiation of $L$. donovani [96, 102-104] and L. infantum $[89,105]$ parasites. Recently, using large-scale approaches, many groups have identified developmentally regulated proteins by comparing expression patterns of soluble and whole cell lysate proteins of either $L$. donovani and L. infantum in vitro axenic promastigotes, as well as induced axenic amastigote forms [95, 97, 105].

Drug screening assays are available for promastigotes, axenic, and intracellular amastigote forms and for parasite infected animal models. Intracellular amastigotes, the parasite form adapted to live inside host cells, are the ideal sample for high-throughput screening assays [8]. A recent study used an automated high-throughput screening assay to discover new antileishmanial compounds and brought promising candidates to the leishmaniasis drug discovery pipeline [65]. In addition, the same group elegantly applied an image-based high-throughput approach and developed computer-assisted algorithms to interpret the infection images and quantify the activities of the antiparasitic compounds [106].

Because leishmaniasis management relies on drug treatment, drug resistant parasites are a major challenge to this field. However, the mechanisms responsible for drug resistance are only partially understood. Therefore, to elucidate the molecular mechanisms of drug resistance, several studies examined differences in protein expression pattern between drug susceptible and resistant parasites using comparative proteomics [68]. Specifically, proteomic screening was employed to evaluate drug resistance to methotrexate and antimony in L. major, L. donovani, and L. infantum [98, 107110]. These studies also contributed to a better understanding of the parasite biology and its response to treatment.

Our group used the proteomic approach to search for new chemotherapeutic leishmanial targets and to modulate these targets to control Leishmania infection. In this study, CBA mouse model of cutaneous leishmaniasis [111] that is highly susceptible to infection in vivo with L. amazonensis was used. In addition, macrophages from the same strain of mice are permissive to L. amazonensis infection in vitro [112]. Proteomic analysis was performed to search for new targets with potential for chemotherapeutic intervention in these macrophages infected with L. amazonensis [113]. Thereby, we identified a set of proteins with modulated expression in macrophages infected with L. amazonensis [113]. Our strategy was to select from among these modulated proteins those with the potential to be modulated by drugs that could act not only on the target present in the host cell, but also on targets present in the parasite. Among them, we selected 
TABLE 3: High-throughput strategies to identify targets in several diseases of different causes.

\begin{tabular}{|c|c|c|}
\hline Disease/pathogen & Use of high throughput & Main result \\
\hline $\begin{array}{l}\text { Leishmania infantum } \\
\text { chagasi }\end{array}$ & $\begin{array}{l}\text { Mechanisms involved in } \\
\text { parasite resistance to } \\
\text { treatment }\end{array}$ & $\begin{array}{l}\text { Identification of } 32 \text { differentially expressed proteins in miltefosine } \\
\text { sensitive and resistant parasites using comparative proteomics [69] }\end{array}$ \\
\hline Leishmania infantum & $\begin{array}{l}\text { Mechanisms involved in } \\
\text { parasite resistance to } \\
\text { treatment }\end{array}$ & $\begin{array}{l}\text { Identification of } 97 \text { differentially expressed proteins in amphotericin } \\
\text { B-sensitive and -resistant parasites using quantitative proteomics [70] }\end{array}$ \\
\hline Trypanosoma cruzi & $\begin{array}{l}\text { Mechanisms involved in } \\
\text { parasite resistance to } \\
\text { treatment }\end{array}$ & $\begin{array}{l}\text { Identification of proteins involved in the effect of naphthoimidazoles } \\
\text { N1, N2 and N3 on the parasite using proteomics [71] }\end{array}$ \\
\hline Trypanosoma cruzi & $\begin{array}{l}\text { Mechanisms of drug action } \\
\text { and resistance }\end{array}$ & $\begin{array}{l}\text { Identification of proteins that could be related to benznidazole } \\
\text { reductive activation and/or resistance mechanisms [72] }\end{array}$ \\
\hline Trypanosoma brucei & Drug development & $\begin{array}{l}\text { Proteomics study showing that 2,4-diaminopyrimidines have a good } \\
\text { in vitro and in vivo pharmacological profile against trypanosomatid } \\
\text { protozoans [73] }\end{array}$ \\
\hline Toxoplasma gondii & $\begin{array}{l}\text { Mechanisms involved in } \\
\text { parasite resistance to } \\
\text { treatment }\end{array}$ & $\begin{array}{l}\text { First proteomics insights into sulfadiazine resistance in T. gondii } \\
\text { resistant strains isolated from clinical cases [74] }\end{array}$ \\
\hline Plasmodium falciparum & $\begin{array}{l}\text { Drug development and } \\
\text { mechanisms of drug action }\end{array}$ & $\begin{array}{l}\text { Proteomics study showing that indolone- } \mathrm{N} \text {-oxide causes a profound } \\
\text { destabilization of the malaria-infected erythrocytes membrane } \\
\text { through a mechanism apparently triggered by the activation of a } \\
\text { redox signaling pathway rather than direct oxidative damage [75] }\end{array}$ \\
\hline Plasmodium falciparum & $\begin{array}{l}\text { Mechanisms involved in } \\
\text { parasite resistance to } \\
\text { treatment }\end{array}$ & $\begin{array}{l}\text { Identification of a specific response to doxycycline treatment, } \\
\text { involving mitochondrion and apicoplast [76] }\end{array}$ \\
\hline Mycobacterium tuberculosis & $\begin{array}{l}\text { Identification of markers of } \\
\text { treatment response }\end{array}$ & $\begin{array}{l}\text { Identification of a nonculture based, five-marker signature predictive } \\
\text { of } 8 \text {-week culture status using proteomics [77] }\end{array}$ \\
\hline Neisseria gonorrhoeae & $\begin{array}{l}\text { Drug resistance and } \\
\text { mechanisms of drug action }\end{array}$ & $\begin{array}{l}\text { Comparative proteomics study providing knowledge of the mode of } \\
\text { action of antibiotic and secondary target proteins implicated in } \\
\text { adaptation and compensatory mechanisms [78] }\end{array}$ \\
\hline Staphylococcus aureus & $\begin{array}{l}\text { Drug development and } \\
\text { mechanisms of drug action }\end{array}$ & $\begin{array}{l}\text { Proteomics study showing that MntABC might be a potential } \\
\text { therapeutic target for the development of antibiotics and that in vivo } \\
\text { proteomics data will serve as a valuable basis for defining potential } \\
\text { antigen combinations for multicomponent vaccines [79] }\end{array}$ \\
\hline Cancer & $\begin{array}{l}\text { Drug development and } \\
\text { mechanisms of drug action }\end{array}$ & $\begin{array}{l}\text { First proteomic analysis regarding Aubipy }{ }_{c} \text { cytotoxicity in A2780/S } \\
\text { ovarian cancer cell line showing that Aubipy } y_{c} \text { treatment affected, } \\
\text { directly or indirectly, several glycolytic enzymes }[80]\end{array}$ \\
\hline Cancer & Drug development & $\begin{array}{l}\text { Proteomics study showing that several metabolism-related proteins, } \\
\text { molecular chaperons, and proteins involved in signaling are } \\
\text { differently expressed after targeted chemotherapeutic treatment } \\
\text { (Daunorubicin-GnRH-III Derivative Bioconjugate), leading to the } \\
\text { conclusion that the bioconjugate exerts its cytotoxic action by } \\
\text { interfering with multiple intracellular processes [81] }\end{array}$ \\
\hline Cancer & $\begin{array}{l}\text { Drug development and } \\
\text { mechanisms of drug action }\end{array}$ & $\begin{array}{l}\text { Proteomics study showing differential protein expression after } \\
\text { treatment of Hepatocellular Carcinoma Cell Lines with Alendronate } \\
{[82]}\end{array}$ \\
\hline
\end{tabular}

the transcription factor hypoxia-inducible factor- (HIF-) $1 \alpha$ for study. This transcription factor is one of the client proteins for the heat shock protein 90 (HSP90), which is a molecular chaperone that is highly conserved among organisms from different kingdoms, such as bacteria, yeast, and eukaryotic cells [114]. Notably, HSP90 is expressed both in macrophages and in Leishmania $[115,116]$. Some molecules with anticancer activity that act against HIF- $1 \alpha$ actually act against HSP90. Below, we will further discuss evidence of the antileishmanial effect of chemicals that modulate HSP90.

\section{HSP90}

The heat shock protein 90 (HSP90) is ubiquitously expressed throughout all kingdoms, except Archaea [115, 116]. Its main function is to serve as molecular chaperone helping the correct folding of nascent proteins, avoiding miss-folding and protein aggregate formation. This molecular chaperone is expressed in physiological conditions, accounting as much as $2 \%$ of the total soluble proteins in the cell and up to $10 \%$ in cells under stress [117-120]. HSP90 functions as 
a dimeric ATP-dependent chaperone. The ATP-binding pocket is located in the N-terminal site of the protein; the middle domain is used to interact with client protein and cochaperones while the C-terminal is used in the dimerization process. The ATP-biding site at the $\mathrm{N}$-terminal region of the HSP90 can be specifically inhibited upon by ansamycinbenzoquinone antibiotics, such as the geldanamycin (GA), its derivatives, and other small molecules. GA and other HSP90 inhibitors act by competing with high affinity against the ATP for the ATP-ase pocket at the N-terminal domain of the HSP90 [121, 122]. Once the ATP-ase activity of the HSP90 is shut, nascent, unfolded, misfolded, and client proteins are ubiquitinated and degraded through the proteasome pathway [123]. Since HSP90 controls hundreds of proteins expression including several oncoproteins, many HSP90 inhibitors have been tested as anticancer drugs including the 17-(allylamino)17- demethoxygeldanamycin (17-AAG). Several of these compounds have anticancer activity and entered clinical trials as candidates for treatment of different human cancers [124].

Besides of the anticancer activity of those HSP90 inhibitors, some of them have been tested in vitro and in vivo against infectious diseases caused by Plasmodium, Trypanosoma, and Toxoplasma with promising results in the majority of the cases [125-128]. In protozoans, several regulatory proteins, such as tyrosine-kinases, cytoskeletal proteins, histones, transcription factors, and DNA polymerases, require HSP90 interaction in order to complete their folding process $[129,130]$. In Leishmania spp., HSP90 client proteins play essential roles in cell cycle control, cellular signal transduction, and transcription regulation. Inhibition of HSP90 from promastigotes of $L$. donovani induced shape change into rounded cells and reduction of the flagellum, cell cycle arrest in G2 phase, and expression of A2 proteins, typical of amastigote stage of Leishmania parasites [131].

Recently, we have conducted a series of experiments to determine the effect of HSP90 pharmacologic inhibition on the outcome of the infection caused by L. amazonensis. So far, we have tested three different HSP90 inhibitors, GA, 17AAG, and radicicol (RD). We obtained similar in vitro results regarding intracellular parasite killing [132].

First, we assessed the ability of 17-AAG to kill extracellular promastigote parasites. We observed, by direct counting, that 17-AAG inhibits L. amazonensis growth at a nanomolar range $(65 \pm 7 \mathrm{nM})$. We also showed that $17-\mathrm{AAG}$ is able to reduce the percentage of macrophage infection and the parasite burden in a time-dose dependent manner with an $\mathrm{EC}_{50}$ of $149 \pm$ $7 \mathrm{nM}$. On the other hand, the dose able to reduce macrophage viability by $50 \%\left(\mathrm{CC}_{50}\right)$ is $10,830 \pm 1,700 \mathrm{nM}$, as assessed by Alamar Blue assay. As result, we show that $17-\mathrm{AAG}$ has a selective index (SI) of 72.68 . This means that $17-\mathrm{AAG}$ is 72 times more efficient against intracellular Leishmania than the macrophage host cell. These results are very promising since high doses used in cancer patients from clinical trials might not be needed for the treatment of leishmaniases or other parasitic diseases [132, 133].

Another important observation is the fact that 17-AAG is able to kill both promastigotes and amastigotes forms of the Leishmania. Similarly to the effect on promastigote forms and on early-phagocytized parasites and on intracellular completed differentiated amastigote, 17-AAG causes parasite death in a dose-time dependent manner. This is an essential observation since the amastigote is the persistent form found in mammalian host cells [134]. These results were the final step before the use of 17-AAG in the murine models of leishmaniases. To date, we have tested 17-AAG in a $L$. braziliensis, BALB/c murine model. 17-AAG, in this model, has proven to be efficient, reducing the lesion size and parasite burden after intraperitoneal treatment. However, draining lymph nodes did not have their parasite burden reduced by the treatment [133].

We also observed that treatment of infected macrophages with 17-AAG actually reduces proinflammatory cytokines and chemokines like TNF-alpha and MCP-1, known to play a role in parasite clearance. 17-AAG treatment also inhibits superoxide and nitric oxide (NO) production by infected macrophages, both known as leishmanicidal molecules [132, 133]. Previous data from the literature supports the notion that 17-AAG and other HSP90 inhibitors actually act as an anti-inflammatory molecule in different models [135137]. Reduced NO production might be explained by the fact that iNOS itself is a client protein of HSP90 and it has been shown that HSP90 inhibition reduces NO production in other models $[138,139]$. This might provide 17AAG with an advantage, since in lesions of patients with cutaneous and mucocutaneous leishmaniasis intense inflammatory response is observed with exacerbated IFN-gamma, TNF-alpha, and oxidative response that causes tissue damage.

We also observed that 17-AAG induces intense parasite vacuolization with autophagic features [132]. To date, it seems that autophagy plays a role in parasite death, but it is hard to determine if Leishmania parasite is suffering an autophagic cell death [119]. To prove that it would be necessary to block the autophagic pathway and observe an increase in parasite viability after 17-AAG treatment. Although autophagy is required for housekeeping processes and promastigote to amastigote differentiation in Leishmania, it would be interesting to investigate the role autophagy actually plays in Leishmania death caused by 17-AAG.

It is clear that HSP90 plays an important role in parasite housekeeping, metabolism, and cell cycle, particularly considering the huge number of client proteins that are under HSP90 control. Our data support the idea that HSP90 serves as a major molecular target for chemotherapy intervention in parasitic diseases especially in leishmaniases. The main advantage of HSP90 inhibition for leishmaniasis treatment is the possibility of attacking several parasite regulatory proteins with a single drug. Besides that, the treatment range of nanomolar and a SI of 72.68 are very promising, especially considering that 17-AAG and other HSP90 inhibitors have been or are being tested as anticancer drugs in clinical trials. In sum, these results indicate that HSP90 is an interesting molecular target that should be more explored specially regarding parasitic disease treatment. In addition, our findings support the notion that 17-AAG as well as other HSP90 inhibitors are promising antileishmanial drugs that could be used alone or as synergistic drugs with the aim of reducing toxicity and resistance and increase potency $[132,133]$. 


\section{Concluding Remarks}

The search for new antileishmanials is due to the lack in the available drugs for leishmaniasis treatment as they can have high toxicity, be used a long term, and cause severe adverse reactions. This often leads to treatment abandonment and failure. In addition, many current antileishmanials do not eliminate the parasites completely from all infected individuals and have only species-specific activity. Alternative protocols, such as the rational combination of drugs or combinations of immunotherapy and antileishmanial drugs, have favorably reduced individual doses, treatment duration, and adverse effects. However, comprehensive long-term studies need to be developed to determine the actual efficacy of these alternative protocols. Controlled release systems, such as liposomes and nanoparticles, provide a greater efficacy and safety once drugs are adsorbed or encapsulated in carriers, reducing the dose and adverse reactions of conventional formulations. In addition, to address the efficacy of these new antileishmanial formulations, in vivo studies should also be conducted.

In order to identify new chemotherapeutic targets for control of Leishmania infection, high-throughput studies have proven to be useful. Between microarray and proteomics approaches, data in the literature support the idea that proteomics is superior to microarray for the discovery of new therapeutic strategies in diseases caused by pathogens, being also widely employed to study Leishmania for screening of drug resistance in various Leishmania species. Our group using proteomics was able to identify among a set of proteins in infected macrophages new targets with potential for chemotherapeutic intervention. As described above, we demonstrated that chemicals that inhibit one of these targets have shown a potent antileishmanial effect.

\section{Conflict of Interests}

The authors declare that there is no conflict of interests regarding the publication of this paper.

\section{References}

[1] WHO, Control of the Leishmaniases, WHO Technical Report Series, WHO, Geneva, Switzerland, 2010.

[2] G. Grimaldi Jr. and R. B. Tesh, "Leishmaniases of the New World: current concepts and implications for future research," Clinical Microbiology Reviews, vol. 6, no. 3, pp. 230-250, 1993.

[3] H. W. Murray, J. D. Berman, C. R. Davies, and N. G. Saravia, "Advances in leishmaniasis," The Lancet, vol. 366, no. 9496, pp. 1561-1577, 2005.

[4] P. Desjeux, "Leishmaniasis: current situation and new perspectives," Comparative Immunology, Microbiology and Infectious Diseases, vol. 27, no. 5, pp. 305-318, 2004.

[5] R. W. Ashford, "The leishmaniases as emerging and reemerging zoonoses," International Journal for Parasitology, vol. 30, no. 1213, pp. 1269-1281, 2000.

[6] P. Trouiller, P. Olliaro, E. Torreele, J. Orbinski, R. Laing, and N. Ford, "Drug development for neglected diseases: a deficient market and a public-health policy failure," The Lancet, vol. 359, no. 9324, pp. 2188-2194, 2002.
[7] A. R. Renslo and J. H. McKerrow, "Drug discovery and development for neglected parasitic diseases," Nature Chemical Biology, vol. 2, no. 12, pp. 701-710, 2006.

[8] A. K. Cruz, J. S. de Toledo, M. Falade et al., "Current treatment and drug discovery against Leishmania spp. and Plasmodium spp.: a review," Current Drug Targets, vol. 10, no. 3, pp. 178-192, 2009.

[9] V. S. Amato, F. F. Tuon, H. A. Bacha, V. A. Neto, and A. C. Nicodemo, "Mucosal leishmaniasis: current scenario and prospects for treatment," Acta Tropica, vol. 105, no. 1, pp. 1-9, 2008.

[10] J. van Griensven, M. Balasegaram, F. Meheus, J. Alvar, L. Lynen, and M. Boelaert, "Combination therapy for visceral leishmaniasis," The Lancet Infectious Diseases, vol. 10, no. 3, pp. 184-194, 2010.

[11] P. L. Olliaro and A. D. M. Bryceson, "Practical progress and new drugs for changing patterns of leishmaniasis," Parasitology Today, vol. 9, no. 9, pp. 323-328, 1993.

[12] J. D. Berman, "Human leishmaniasis: clinical, diagnostic, and chemotherapeutic developments in the last 10 years," Clinical Infectious Diseases, vol. 24, no. 4, pp. 684-703, 1997.

[13] L. H. Freitas-Junior, E. Chatelain, H. A. Kim, and J. L. SiqueiraNeto, "Visceral leishmaniasis treatment: what do we have, what do we need and how to deliver it?" International Journal for Parasitology: Drugs and Drug Resistance, vol. 2, pp. 11-19, 2012.

[14] T. S. Tiuman, A. O. Santos, T. Ueda-Nakamura, B. P. D. Filho, and C. V. Nakamura, "Recent advances in leishmaniasis treatment," International Journal of Infectious Diseases, vol. 15, no. 8, pp. e525-e532, 2011.

[15] S. L. Croft and V. Yardley, "Chemotherapy of leishmaniasis," Current Pharmaceutical Design, vol. 8, no. 4, pp. 319-342, 2002.

[16] S. L. Croft and G. H. Coombs, "Leishmaniasis-current chemotherapy and recent advances in the search for novel drugs," Trends in Parasitology, vol. 19, no. 11, pp. 502-508, 2003.

[17] Y. Melaku, S. M. Collin, K. Keus, F. Gatluak, K. Ritmeijer, and R. N. Davidson, "Treatment of kala-azar in southern Sudan using a 17-day regimen of sodium stibogluconate combined with paromomycin: a retrospective comparison with 30-day sodium stibogluconate monotherapy," American Journal of Tropical Medicine and Hygiene, vol. 77, no. 1, pp. 89-94, 2007.

[18] C. P. Thakur, S. Narayan, and A. Ranjan, "Epidemiological, clinical \& pharmacological study of antimony-resistant visceral leishmaniasis in Bihar, India," Indian Journal of Medical Research, vol. 120, no. 3, pp. 166-172, 2004.

[19] F. Frézard, C. Demicheli, and R. R. Ribeiro, "Pentavalent antimonials: new perspectives for old drugs," Molecules, vol. 14, no. 7, pp. 2317-2336, 2009.

[20] S. Sundar, "Drug resistance in Indian visceral leishmaniasis," Tropical Medicine and International Health, vol. 6, no. 11, pp. 849-854, 2001.

[21] S. L. Croft, K. Seifert, and V. Yardley, "Current scenario of drug development for leishmaniasis," Indian Journal of Medical Research, vol. 123, no. 3, pp. 399-410, 2006.

[22] S. L. Croft and P. Olliaro, "Leishmaniasis chemotherapychallenges and opportunities," Clinical Microbiology and Infection, vol. 17, no. 10, pp. 1478-1483, 2011.

[23] F. Meheus, M. Balasegaram, P. Olliaro et al., "Cost-effectiveness analysis of combination therapies for visceral leishmaniasis in the Indian subcontinent," PLoS Neglected Tropical Diseases, vol. 4, no. 9, article e818, 2010.

[24] N. Singh, M. Kumar, and R. K. Singh, "Leishmaniasis: current status of available drugs and new potential drug targets," Asian 
Pacific Journal of Tropical Medicine, vol. 5, no. 6, pp. 485-497, 2012.

[25] P. G. Bray, M. P. Barrett, S. A. Ward, and H. P. De Koning, "Pentamidine uptake and resistance in pathogenic protozoa: past, present and future," Trends in Parasitology, vol. 19, no. 5, pp. 232-239, 2003.

[26] K. Jain and N. K. Jain, "Novel therapeutic strategies for treatment of visceral leishmaniasis," Drug Discovery Today, vol. 18, no. 23-24, pp. 1272-1281, 2013.

[27] D. Fong, M. M.-Y. Chan, R. Rodriguez, L. J. Gately, J. D. Berman, and M. Grogl, "Paromomycin resistance in Leishmania tropica: lack of correlation with mutation in the small subunit ribosomal RNA gene," American Journal of Tropical Medicine and Hygiene, vol. 51, no. 6, pp. 758-766, 1994.

[28] A. Jhingran, B. Chawla, S. Saxena, M. P. Barrett, and R. Madhubala, "Paromomycin: uptake and resistance in Leishmania donovani," Molecular and Biochemical Parasitology, vol. 164, no. 2, pp. 111-117, 2009.

[29] S. Hendrickx, R. A. I. da Luz, V. Bhandari et al., "Experimental induction of paromomycin resistance in antimony-resistant strains of $L$. donovani: outcome dependent on in vitro selection protocol," PLoS Neglected Tropical Diseases, vol. 6, no. 5, Article ID e1664, 2012.

[30] H. Sindermann, S. L. Croft, K. R. Engel et al., "Miltefosine (Impavido): the first oral treatment against leishmaniasis," Medical Microbiology and Immunology, vol. 193, no. 4, pp. 173180, 2004.

[31] V. Yeo-Gamarra, C. Rodriguez-Ulhoa, C. Diaz-Velez et al., "Sa 1914 sequential versus triple standard therapy for Helicobacter pylori eradication," Gastroenterology, vol. 144, no. 5, p. S-333, 2013.

[32] S. Sundar and P. L. Olliaro, "Miltefosine in the treatment of leishmaniasis: clinical evidence for informed clinical risk management," Therapeutics and Clinical Risk Management, vol. 3, no. 5, pp. 733-740, 2007.

[33] E. Kandil, "Treatment of cutaneous leishmaniasis with trimethoprim sulfamethoxazole combination," Dermatologica, vol. 146, no. 5, pp. 303-309, 1973.

[34] Z. Even-Paz, L. Weinrauch, R. Livshin, J. El-On, and C. L. Greenblatt, "Rifampicin treatment of cutaneous leishmaniasis," International Journal of Dermatology, vol. 21, no. 2, pp. 110-112, 1982.

[35] M. Z. Hossain, "Combination therapy (momomycine and methyluracil) in leishmaniasis cutis," International Journal of Dermatology, vol. 27, no. 10, pp. 720-722, 1988.

[36] P. D. Marsden, C. C. Cuba, A. C. Barreto, R. N. Sampaio, and R. A. A. Rocha, "Nifurtimox in the treatment of South American leishmaniasis," Transactions of the Royal Society of Tropical Medicine and Hygiene, vol. 73, no. 4, pp. 391-394, 1979.

[37] A. Masmoudi, A. Dammak, H. Chaaben, N. Maalej, F. Akrout, and H. Turki, "Doxycycline for the treatment of cutaneous leishmaniasis," Dermatology Online Journal, vol. 14, no. 8, p. 22, 2008.

[38] D. C. Miguel, J. K. U. Yokoyama-Yasunaka, and S. R. B. Uliana, "Tamoxifen is effective in the treatment of Leishmania amazonensis infections in mice," PLoS Neglected Tropical Diseases, vol. 2, no. 6, article e249, 2008.

[39] D. C. Miguel, R. C. Zauli-Nascimento, J. K. U. YokoyamaYasunaka, S. Katz, C. L. Barbiéri, and S. R. B. Uliana, “Tamoxifen as a potential antileishmanial agent: efficacy in the treatment of Leishmania braziliensisand Leishmania chagasi infections," Journal of Antimicrobial Chemotherapy, vol. 63, no. 2, pp. 365$368,2009$.
[40] J. Alvar, S. Croft, and P. Olliaro, "Chemotherapy in the treatment and control of leishmaniasis," Advances in Parasitology, vol. 61, pp. 223-274, 2006.

[41] F. Astelbauer and J. Walochnik, "Antiprotozoal compounds: state of the art and new developments," International Journal of Antimicrobial Agents, vol. 38, no. 2, pp. 118-124, 2011.

[42] D. C. Miguel, J. K. U. Yokoyama-Yasunaka, W. K. Andreoli, R. A. Mortara, and S. R. B. Uliana, "Tamoxifen is effective against Leishmania and induces a rapid alkalinization of parasitophorous vacuoles harbouring Leishmania (Leishmania) amazonensis amastigotes," Journal of Antimicrobial Chemotherapy, vol. 60, no. 3, pp. 526-534, 2007.

[43] J. V. Richard and K. A. Werbovetz, "New antileishmanial candidates and lead compounds," Current Opinion in Chemical Biology, vol. 14, no. 4, pp. 447-455, 2010.

[44] S. Wyllie, S. Patterson, L. Stojanovski et al., "The antitrypanosome drug fexinidazole shows potential for treating visceral leishmaniasis," Science Translational Medicine, vol. 4, no. 119, Article ID 119re1, 2012.

[45] P. Minodier and P. Parola, "Cutaneous leishmaniasis treatment," Travel Medicine and Infectious Disease, vol. 5, no. 3, pp. 150-158, 2007.

[46] I. Arevalo, B. Ward, R. Miller et al., "Successful treatment of drug-resistant cutaneous leishmaniasis in humans by use of imiquimod, an immunomodulator," Clinical Infectious Diseases, vol. 33, no. 11, pp. 1847-1851, 2001.

[47] C. Miranda-Verastegui, G. Tulliano, T. W. Gyorkos et al., "Firstline therapy for human cutaneous leishmaniasis in Peru using the TLR7 agonist imiquimod in combination with pentavalent antimony," PLoS Neglected Tropical Diseases, vol. 3, no. 7, article e491, 2009.

[48] S. Sundar, P. K. Sinha, M. Rai et al., "Comparison of short-course multidrug treatment with standard therapy for visceral leishmaniasis in India: an open-label, non-inferiority, randomised controlled trial," The Lancet, vol. 377, no. 9764, pp. 477-486, 2011.

[49] K. Seifert and S. L. Croft, "In vitro and in vivo interactions between miltefosine and other antileishmanial drugs," Antimicrobial Agents and Chemotherapy, vol. 50, no. 1, pp. 73-79, 2006.

[50] S. Bimal, S. Sinha, S. K. Singh et al., "Leishmania donovani: CD2 biased immune response skews the SAG mediated therapy for a predominant Th1 response in experimental infection," Experimental Parasitology, vol. 131, no. 3, pp. 274-282, 2012.

[51] N. Shakya, S. A. Sane, P. Vishwakarma, and S. Gupta, "Enhancement in therapeutic efficacy of miltefosine in combination with synthetic bacterial lipopeptide, Pam3Cys against experimental Visceral Leishmaniasis," Experimental Parasitology, vol. 131, no. 3, pp. 377-382, 2012.

[52] M. Hamidi, A. Azadi, and P. Rafiei, "Hydrogel nanoparticles in drug delivery," Advanced Drug Delivery Reviews, vol. 60, no. 15, pp. 1638-1649, 2008.

[53] L. Brannon-Peppas, "Controlled release of beta-estradiol from biodegradable microparticles within a silicone matrix," Journal of Biomaterials Science (Polymer Edition), vol. 5, no. 4, pp. 339351, 1994.

[54] M. Petitti, M. Vanni, and A. A. Barresi, "Controlled release of drug encapsulated as a solid core: theoretical model and sensitivity analysis," Chemical Engineering Research and Design, vol. 86, no. 11, pp. 1294-1300, 2008.

[55] M. Solomon, F. Pavlotzky, A. Barzilai, and E. Schwartz, "Liposomal amphotericin B in comparison to sodium stibogluconate 
for Leishmania braziliensis cutaneous leishmaniasis in travelers," Journal of the American Academy of Dermatology, vol. 68, no. 2, pp. 284-289, 2013.

[56] M. Solomon, S. Baum, A. Barzilai, A. Scope, H. Trau, and E. Schwartz, "Liposomal amphotericin B in comparison to sodium stibogluconate for cutaneous infection due to Leishmania braziliensis," Journal of the American Academy of Dermatology, vol. 56, no. 4, pp. 612-616, 2007.

[57] S. Burza, R. Mahajan, P. K. Sinha et al., "Visceral leishmaniasis and HIV co-infection in Bihar, India: long-term effectiveness and treatment outcomes with liposomal amphotericin B (AmBisome)," PLoS Neglected Tropical Diseases, vol. 8, no. 8, Article ID e3053, 2014.

[58] K. Ritmeijer, R. Ter Horst, S. Chane et al., "Limited effectiveness of high-dose liposomal amphotericin B (AmBisome) for treatment of visceral leishmaniasis in an ethiopian population with high HIV prevalence," Clinical Infectious Diseases, vol. 53, no. 12, pp. e152-e158, 2011.

[59] J. Roychoudhury, R. Sinha, and N. Ali, "Therapy with sodium stibogluconate in stearylamine-bearing liposomes confers cure against SSG-resistant Leishmania donovani in BALB/c mice," PLoS ONE, vol. 6, no. 3, Article ID e17376, 2011.

[60] M. T. Shio, M. Paquet, C. Martel et al., "Drug delivery by tattooing to treat cutaneous leishmaniasis," Scientific Reports, vol. 4, article 4156, 2014.

[61] V. K. Prajapati, K. Awasthi, S. Gautam et al., "Targeted killing of Leishmania donovani in vivo and in vitro with amphotericin B attached to functionalized carbon nanotubes," Journal of Antimicrobial Chemotherapy, vol. 66, no. 4, pp. 874-879, 2011.

[62] P. Saudagar and V. K. Dubey, "Carbon nanotube based betulin formulation shows better efficacy against Leishmania parasite," Parasitology International, vol. 63, no. 6, pp. 772-776, 2014.

[63] T. G. Ribeiro, M. A. Chávez-Fumagall, D. G. Valadares et al., "Novel targeting using nanoparticles: an approach to the development of an effective anti-leishmanial drug-delivery system," International Journal of Nanomedicine, vol. 9, no. 1, pp. 877-890, 2014.

[64] E. R. Sharlow, D. Close, T. Shun et al., "Identification of potent chemotypes targeting Leishmania major using a highthroughput, low-stringency, computationally enhanced, small molecule screen," PLoS Neglected Tropical Diseases, vol. 3, no. 11, article e540, 2009.

[65] J. L. Siqueira-Neto, O.-R. Song, H. Oh et al., "Antileishmanial high-throughput drug screening reveals drug candidates with new scaffolds," PLoS Neglected Tropical Diseases, vol. 4, no. 5, article e675, 2010.

[66] Y. Osorio, B. L. Travi, A. R. Renslo, A. G. Peniche, and P. C. Melby, "Identification of small molecule lead compounds for visceral leishmaniasis using a novel ex vivo splenic explant model system," PLoS Neglected Tropical Diseases, vol. 5, no. 2, article e962, 2011.

[67] S. Kumari, A. Kumar, M. Samant, N. Singh, and A. Dube, "Discovery of novel vaccine candidates and drug targets against visceral leishmaniasis using proteomics and transcriptomics," Current Drug Targets, vol. 9, no. 11, pp. 938-947, 2008.

[68] D. Paape and T. Aebischer, "Contribution of proteomics of Leishmania spp. to the understanding of differentiation, drug resistance mechanisms, vaccine and drug development," Journal of Proteomics, vol. 74, no. 9, pp. 1614-1624, 2011.

[69] J. B. Carnielli, H. M. de Andrade, S. F. Pires et al., "Proteomic analysis of the soluble proteomes of miltefosine-sensitive and -resistant Leishmania infantum chagasi isolates obtained from
Brazilian patients with different treatment outcomes," Journal of Proteomics, vol. 108, pp. 198-208, 2014.

[70] M.-C. Brotherton, S. Bourassa, D. Légaré, G. G. Poirier, A. Droit, and M. Ouellette, "Quantitative proteomic analysis of amphotericin B resistance in Leishmania infantum," International Journal for Parasitology: Drugs and Drug Resistance, vol. 4, no. 2, pp. 126-132, 2014.

[71] R. F. S. Menna-Barreto, D. G. Beghini, A. T. S. Ferreira, A. V. Pinto, S. L. de Castro, and J. Perales, "A proteomic analysis of the mechanism of action of naphthoimidazoles in Trypanosoma cruzi epimastigotes in vitro," Journal of Proteomics, vol. 73, no. 12, pp. 2306-2315, 2010.

[72] A. Trochine, G. Alvarez, S. Corre et al., "Trypanosoma cruzi chemical proteomics using immobilized benznidazole," Experimental Parasitology, vol. 140, no. 1, pp. 33-38, 2014.

[73] L. Mercer, T. Bowling, J. Perales et al., "2,4-Diaminopyrimidines as potent inhibitors of trypanosoma brucei and identification of molecular targets by a chemical proteomics approach," PLoS Neglected Tropical Diseases, vol. 5, no. 2, article e956, 2011.

[74] C. Doliwa, D. Xia, S. Escotte-Binet et al., "Identification of differentially expressed proteins in sulfadiazine resistant and sensitive strains of Toxoplasma gondii using difference-gel electrophoresis (DIGE)," International Journal for Parasitology: Drugs and Drug Resistance, vol. 3, pp. 35-44, 2013.

[75] A. Pantaleo, E. Ferru, R. Vono et al., "New antimalarial indolone-N-oxides, generating radical species, destabilize the host cell membrane at early stages of Plasmodium falciparum growth: role of band 3 tyrosine phosphorylation," Free Radical Biology and Medicine, vol. 52, no. 2, pp. 527-536, 2012.

[76] S. Briolant, L. Almeras, M. Belghazi et al., "Plasmodium falciparum proteome changes in response to doxycycline treatment," Malaria Journal, vol. 9, no. 1, article 141, 2010.

[77] P. Nahid, E. Bliven-Sizemore, L. G. Jarlsberg et al., "Aptamerbased proteomic signature of intensive phase treatment response in pulmonary tuberculosis," Tuberculosis, vol. 94, no. 3, pp. 187-196, 2014.

[78] S. Nabu, R. Lawung, P. Isarankura-Na-Ayudhya, C. IsarankuraNa-Ayudhya, S. Roytrakul, and V. Prachayasittikul, "Reference map and comparative proteomic analysis of Neisseria gonorrhoeae displaying high resistance against spectinomycin," Journal of Medical Microbiology, vol. 63, no. 3, pp. 371-385, 2014.

[79] B. A. Diep, Q. Phung, S. Date et al., "Identifying potential therapeutic targets of methicillin-resistant staphylococcus aureus through in vivo proteomic analysis," Journal of Infectious Diseases, vol. 209, no. 10, pp. 1533-1541, 2014.

[80] T. Gamberi, L. Massai, F. Magherini et al., "Proteomic analysis of A2780/S ovarian cancer cell response to the cytotoxic organogold(III) compound Aubipy," Journal of Proteomics, vol. 103, pp. 103-120, 2014.

[81] V. N. Schreier, L. Petho, E. Orbán et al., "Protein expression profile of HT-29 human colon cancer cells after treatment with a cytotoxic daunorubicin-GnRH-III derivative bioconjugate," PLoS ONE, vol. 9, no. 4, Article ID e94041, 2014.

[82] A. Ilyas, Z. Hashim, N. Naeem, K. Haneef, and S. Zarina, "The effect of alendronate on proteome of hepatocellular carcinoma cell lines," International Journal of Proteomics, vol. 2014, Article ID 532953, 9 pages, 2014.

[83] E. Fischer and U. Sauer, "Large-scale in vivo flux analysis shows rigidity and suboptimal performance of Bacillus subtilis metabolism," Nature Genetics, vol. 37, no. 6, pp. 636-640, 2005.

[84] M. K. Hellerstein, "A critique of the molecular target-based drug discovery paradigm based on principles of metabolic control: 
advantages of pathway-based discovery," Metabolic Engineering, vol. 10, no. 1, pp. 1-9, 2008.

[85] G. Duyk, "Attrition and translation," Science, vol. 302, no. 5645, pp. 603-605, 2003.

[86] J. P. B. Menezes, T. F. Almeida, A. L. O. A. Petersen et al., "Proteomic analysis reveals differentially expressed proteins in macrophages infected with Leishmania amazonensis or Leishmania major," Microbes and Infection, vol. 15, no. 8-9, pp. 579591, 2013.

[87] C. M. Probst, R. A. Silva, J. P. B Menezes et al., "A comparison of two distinct murine macrophage gene expression profiles in response to Leishmania amazonensis infection," BMC Microbiology, vol. 12, article 22, 2012.

[88] J. Osorio y Fortéa, E. de La Llave, B. Regnault et al., “Transcriptional signatures of $\mathrm{BALB} / \mathrm{c}$ mouse macrophages housing multiplying Leishmania amazonensis amastigotes," BMC Genomics, vol. 10, article 119, 2009.

[89] F. McNicoll, J. Drummelsmith, M. Müller et al., "A combined proteomic and transcriptomic approach to the study of stage differentiation in Leishmania infantum," Proteomics, vol. 6, no. 12, pp. 3567-3581, 2006.

[90] N. S. Akopyants, S. W. Clifton, J. Martin et al., "A survey of the Leishmania major Friedlin strain V1 genome by shotgun sequencing: a resource for DNA microarrays and expression profiling," Molecular and Biochemical Parasitology, vol. 113, no. 2, pp. 337-340, 2001.

[91] Y. El Fakhry, M. Ouellette, and B. Papadopoulou, "A proteomic approach to identify developmentally regulated proteins in Leishmania infantum," Proteomics, vol. 2, no. 8, pp. 1007-1017, 2002.

[92] N. S. Akopyants, R. S. Matlib, E. N. Bukanova et al., "Expression profiling using random genomic DNA microarrays identifies differentially expressed genes associated with three major developmental stages of the protozoan parasite Leishmania major," Molecular and Biochemical Parasitology, vol. 136, no. 1, pp. 7186, 2004.

[93] L. R. V. Antonelli, W. O. Dutra, R. P. Almeida, O. Bacellar, and K. J. Gollob, "Antigen specific correlations of cellular immune responses in human leishmaniasis suggests mechanisms for immunoregulation," Clinical and Experimental Immunology, vol. 136, no. 2, pp. 341-348, 2004.

[94] R. C. Duncan, P. Salotra, N. Goyal, N. S. Akopyants, S. M. Beverley, and H. L. Nakhasi, "The application of gene expression microarray technology to kinetoplastid research," Current Molecular Medicine, vol. 4, no. 6, pp. 611-621, 2004.

[95] P. G. Nugent, S. A. Karsani, R. Wait, J. Tempero, and D. F. Smith, "Proteomic analysis of Leishmania mexicana differentiation," Molecular and Biochemical Parasitology, vol. 136, no. 1, pp. 5162, 2004.

[96] A. Saxena, T. Lahav, N. Holland et al., "Analysis of the Leishmania donovani transcriptome reveals an ordered progression of transient and permanent changes in gene expression during differentiation," Molecular and Biochemical Parasitology, vol. 152, no. 1, pp. 53-65, 2007.

[97] M. Thiel and I. Bruchhaus, "Comparative proteome analysis of Leishmania donovani at different stages of transformation from promastigotes to amastigotes," Medical Microbiology and Immunology, vol. 190, no. 1-2, pp. 33-36, 2001.

[98] J. Drummelsmith, V. Brochu, I. Girard, N. Messier, and M. Ouellette, "Proteome mapping of the protozoan parasite Leishmania and application to the study of drug targets and resistance mechanisms," Molecular \& Cellular Proteomics, vol. 2, no. 3, pp. 146-155, 2003.
[99] P. Cuervo, J. B. de Jesus, M. Junqueira et al., "Proteome analysis of Leishmania (Viannia) braziliensis by two-dimensional gel electrophoresis and mass spectrometry," Molecular and Biochemical Parasitology, vol. 154, no. 1, pp. 6-21, 2007.

[100] M. M. Costa, H. M. Andrade, D. C. Bartholomeu et al., "Analysis of Leishmania chagasi by 2-D difference gel eletrophoresis (2-D DIGE) and immunoproteomic: identification of novel candidate antigens for diagnostic tests and vaccine," Journal of Proteome Research, vol. 10, no. 5, pp. 2172-2184, 2011.

[101] E. Handman, "Leishmaniasis: current status of vaccine development," Clinical Microbiology Reviews, vol. 14, no. 2, pp. 229-243, 2001.

[102] P. Salotra, R. C. Duncan, R. Singh, B. V. Subba Raju, G. Sreenivas, and H. L. Nakhasi, "Upregulation of surface proteins in Leishmania donovani isolated from patients of post kala-azar dermal leishmaniasis," Microbes and Infection, vol. 8, no. 3, pp. 637-644, 2006.

[103] N. Singh, R. Almeida, H. Kothari et al., "Differential gene expression analysis in antimony-unresponsive Indian kala azar (visceral leishmaniasis) clinical isolates by DNA microarray," Parasitology, vol. 134, no. 6, pp. 777-787, 2007.

[104] G. Srividya, R. Duncan, P. Sharma, B. V. S. Raju, H. L. Nakhasi, and P. Salotra, "Transcriptome analysis during the process of in vitro differentiation of Leishmania donovani using genomic microarrays," Parasitology, vol. 134, no. 11, pp. 1527-1539, 2007.

[105] K. Leifso, G. Cohen-Freue, N. Dogra, A. Murray, and W. R. McMaster, "Genomic and proteomic expression analysis of Leishmania promastigote and amastigote life stages: the Leishmania genome is constitutively expressed," Molecular and Biochemical Parasitology, vol. 152, no. 1, pp. 35-46, 2007.

[106] J. L. Siqueira-Neto, S. Moon, J. Jang et al., "An image-based highcontent screening assay for compounds targeting intracellular Leishmania donovani amastigotes in human macrophages," PLoS Neglected Tropical Diseases, vol. 6, no. 6, Article ID e1671, 2012.

[107] K. El Fadili, N. Messier, P. Leprohon et al., "Role of the ABC transporter MRPA (PGPA) in antimony resistance in Leishmania infantum axenic and intracellular amastigotes," Antimicrobial Agents and Chemotherapy, vol. 49, no. 5, pp. 19881993, 2005.

[108] A. Mukherjee, P. K. Padmanabhan, S. Singh et al., "Role of ABC transporter MRPA, $\gamma$-glutamylcysteine synthetase and ornithine decarboxylase in natural antimony-resistant isolates of Leishmania donovani," Journal of Antimicrobial Chemother$a p y$, vol. 59, no. 2, pp. 204-211, 2007.

[109] B. Vergnes, B. Gourbal, I. Girard, S. Sundar, J. Drummelsmith, and M. Ouellette, "A proteomics screen implicates HSP83 and a small kinetoplastid calpain-related protein in drug resistance in Leishmania donovani clinical field isolates by modulating drug-induced programmed cell death," Molecular and Cellular Proteomics, vol. 6, no. 1, pp. 88-101, 2007.

[110] K. El Fadili, J. Drummelsmith, G. Roy, A. Jardim, and M. Ouellette, "Down regulation of KMP-11 in Leishmania infantum axenic antimony resistant amastigotes as revealed by a proteomic screen," Experimental Parasitology, vol. 123, no. 1, pp. 51$57,2009$.

[111] V. Lemos de Souza, J. Ascenção Souza, T. M. Correia Silva, P. Sampaio Tavares Veras, and L. A. Rodrigues De-Freitas, "Different Leishmania species determine distinct profiles of immune and histopathological responses in CBA mice," Microbes and Infection, vol. 2, no. 15, pp. 1807-1815, 2000.

[112] I. N. Gomes, A. F. D. C. Calabrich, R. D. S. Tavares, J. Wietzerbin, L. A. R. de Freitas, and P. S. T. Veras, "Differential 
properties of CBA/J mononuclear phagocytes recovered from an inflammatory site and probed with two different species of Leishmania," Microbes and Infection, vol. 5, no. 4, pp. 251-260, 2003.

[113] J. P. B. M. Menezes, T. F. Almeida, A. L. O. A. Petersen et al., "Proteomic analysis reveals differentially expressed proteins in macrophages infected with Leishmania amazonensis or Leishmania major," Microbes and Infection, vol. 15, no. 8-9, pp. 579-591, 2013.

[114] L. Neckers and U. Tatu, "Molecular chaperones in pathogen virulence: emerging new targets for therapy," Cell Host and Microbe, vol. 4, no. 6, pp. 519-527, 2008.

[115] R. S. Gupta, "Phylogenetic analysis of the $90 \mathrm{kD}$ heat shock family of protein sequences and an examination of the relationship among animals, plants, and fungi species," Molecular Biology and Evolution, vol. 12, no. 6, pp. 1063-1073, 1995.

[116] B. Chen, D. Zhong, and A. Monteiro, "Comparative genomics and evolution of the HSP90 family of genes across all kingdoms of organisms," BMC Genomics, vol. 7, article 156, 2006.

[117] B. T. Lai, N. W. Chin, A. E. Stanek, W. Keh, and K. W. Lanks, "Quantitation and intracellular localization of the $85 \mathrm{~K}$ heat shock protein by using monoclonal and polyclonal antibodies," Molecular and Cellular Biology, vol. 4, no. 12, pp. 2802-2810, 1984.

[118] E. A. A. Nollen and R. I. Morimoto, "Chaperoning signaling pathways: molecular chaperones as stress-sensing 'heat shock' proteins," Journal of Cell Science, vol. 115, no. 14, pp. 2809-2816, 2002.

[119] D. J. Klionsky, F. C. Abdalla, H. Abeliovich et al., "Guidelines for the use and interpretation of assays for monitoring autophagy," Autophagy, vol. 8, no. 4, pp. 445-544, 2012.

[120] W. Li, D. Sahu, and F. Tsen, "Secreted heat shock protein-90 (Hsp90) in wound healing and cancer," Biochimica et Biophysica Acta-Molecular Cell Research, vol. 1823, no. 3, pp. 730-741, 2012.

[121] L. Whitesell, E. G. Mimnaugh, B. de Costa, C. E. Myers, and L. M. Neckers, "Inhibition of heat shock protein HSP90pp60v-src heteroprotein complex formation by benzoquinone ansamycins: essential role for stress proteins in oncogenic transformation," Proceedings of the National Academy of Sciences of the United States of America, vol. 91, no. 18, pp. 8324-8328, 1994.

[122] C. Prodromou, S. M. Roe, R. O’Brien, J. E. Ladbury, P. W. Piper, and L. H. Pearl, "Identification and structural characterization of the ATP/ADP-binding site in the Hsp90 molecular chaperone," Cell, vol. 90, no. 1, pp. 65-75, 1997.

[123] J. S. Isaacs, W. Xu, and L. Neckers, "Heat shock protein 90 as a molecular target for cancer therapeutics," Cancer Cell, vol. 3, no. 3, pp. 213-217, 2003.

[124] K. Jhaveri, T. Taldone, S. Modi, and G. Chiosis, "Advances in the clinical development of heat shock protein 90 (Hsp90) inhibitors in cancers," Biochimica et Biophysica Acta-Molecular Cell Research, vol. 1823, no. 3, pp. 742-755, 2012.

[125] H.-J. Ahn, S. Kim, and H.-W. Nam, "Molecular cloning of the $82-\mathrm{kDa}$ heat shock protein (HSP90) of Toxoplasma gondii associated with the entry into and growth in host cells," Biochemical and Biophysical Research Communications, vol. 311, no. 3, pp. 654-659, 2003.

[126] G. Banumathy, V. Singh, S. R. Pavithra, and U. Tatu, "Heat shock protein 90 function is essential for Plasmodium falciparum growth in human erythrocytes," The Journal of Biological Chemistry, vol. 278, no. 20, pp. 18336-18345, 2003.
[127] R. Kumar, A. Musiyenko, and S. Barik, "Plasmodium falciparum calcineurin and its association with heat shock protein 90: mechanisms for the antimalarial activity of cyclosporin A and synergism with geldanamycin," Molecular and Biochemical Parasitology, vol. 141, no. 1, pp. 29-37, 2005.

[128] R. Pallavi, N. Roy, R. K. Nageshan et al., "Heat shock protein 90 as a drug target against protozoan infections: biochemical characterization of HSP90 from plasmodium falciparum and Trypanosoma evansi and evaluation of its inhibitor as a candidate drug," Journal of Biological Chemistry, vol. 285, no. 49, pp. 37964-37975, 2010.

[129] W. B. Pratt and D. O. Toft, "Regulation of signaling protein function and trafficking by the hsp90/hsp70-based chaperone machinery," Experimental Biology and Medicine, vol. 228, no. 2, pp. 111-133, 2003.

[130] A. G. Erlejman, M. Lagadari, J. Toneatto, G. Piwien-Pilipuk, and M. D. Galigniana, "Regulatory role of the $90-\mathrm{kDa}$-heat-shock protein (Hsp90) and associated factors on gene expression," Biochimica et Biophysica Acta, vol. 1839, no. 2, pp. 71-87, 2014.

[131] M. Wiesgigl and J. Clos, "Heat shock protein 90 homeostasis controls stage differentiation in Leishmania donovani," Molecular Biology of the Cell, vol. 12, no. 11, pp. 3307-3316, 2001.

[132] A. L. D. O. A. Petersen, C. E. S. Guedes, C. L. Versoza et al., "17AAG kills intracellular Leishmania amazonensis while reducing inflammatory responses in infected macrophages," PLoS ONE, vol. 7, no. 11, Article ID e49496, 2012.

[133] D. M. Santos, A. L. Petersen, F. S. Celes et al., "Chemotherapeutic Potential of 17-AAG against Cutaneous Leishmaniasis Caused by Leishmania (Viannia) braziliensis," PLoS Neglected Tropical Diseases, vol. 8, no. 10, Article ID e3275, 2014.

[134] J. Alexander and D. G. Russell, "The interaction of leishmania species with macrophages," Advances in Parasitology, vol. 31, pp. 175-254, 1992.

[135] S. Wax, M. Piecyk, B. Maritim, and P. Anderson, "Geldanamycin inhibits the production of inflammatory cytokines in activated macrophages by reducing the stability and translation of cytokine transcripts," Arthritis and Rheumatism, vol. 48, no. 2, pp. 541-550, 2003.

[136] A. Chatterjee, C. Dimitropoulou, F. Drakopanayiotakis et al., "Heat shock protein 90 inhibitors prolong survival, attenuate inflammation, and reduce lung injury in murine sepsis," American Journal of Respiratory and Critical Care Medicine, vol. 176, no. 7, pp. 667-675, 2007.

[137] V. Poulaki, E. Iliaki, N. Mitsiades et al., "Inhibition of Hsp90 attenuates inflammation in endotoxin-induced uveitis," The FASEB Journal, vol. 21, no. 9, pp. 2113-2123, 2007.

[138] B. C. Kone, T. Kuncewicz, W. Zhang, and Z.-Y. Yu, "Protein interactions with nitric oxide synthases: controlling the right time, the right place, and the right amount of nitric oxide," American Journal of Physiology-Renal Physiology, vol. 285, no. 2, pp. F178-F190, 2003.

[139] H. Xu, Y. Shi, J. Wang et al., "A heat shock protein 90 binding domain in endothelial nitric-oxide synthase influences enzyme function," Journal of Biological Chemistry, vol. 282, no. 52, pp. 37567-37574, 2007. 

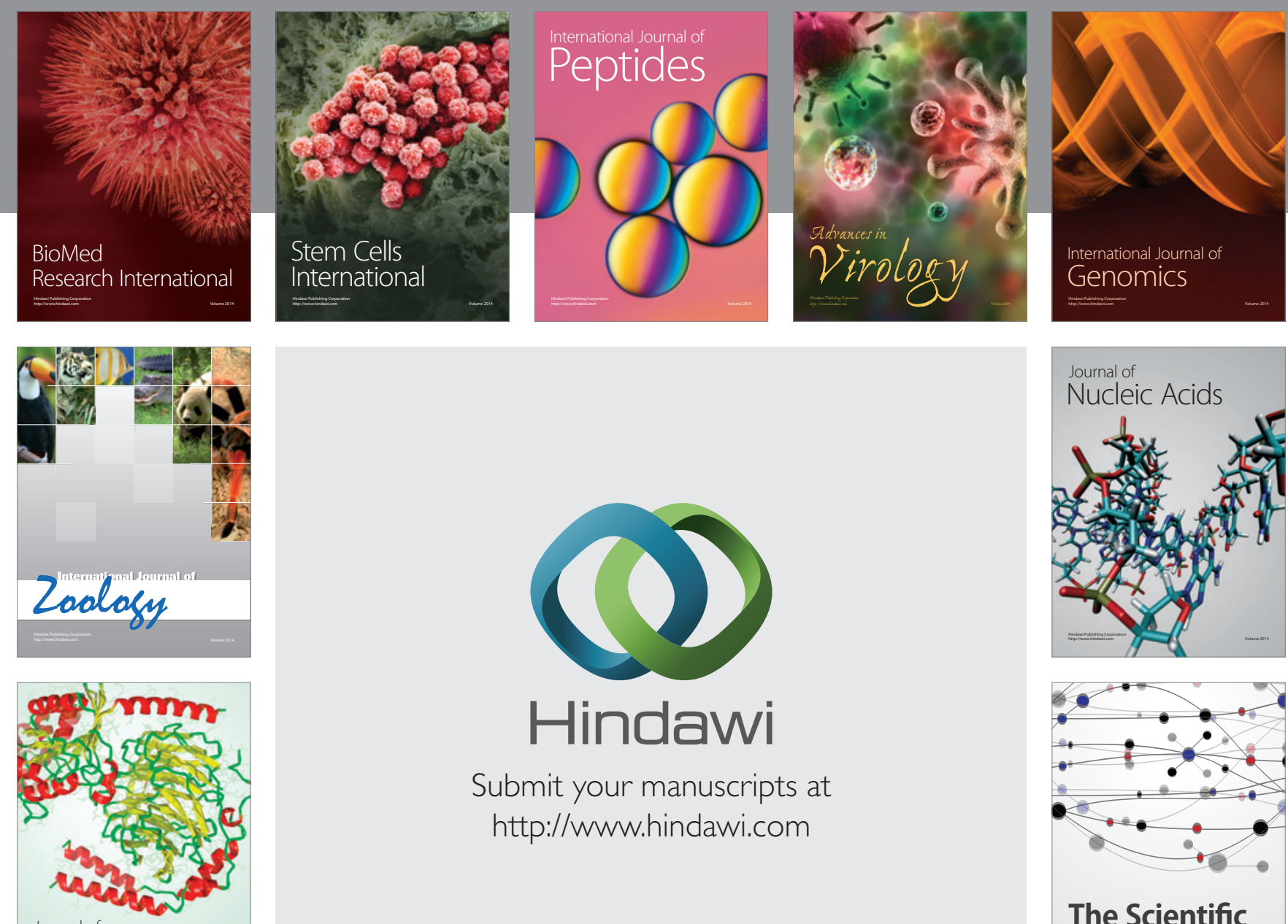

Submit your manuscripts at

http://www.hindawi.com

Journal of
Signal Transduction


The Scientific World Journal
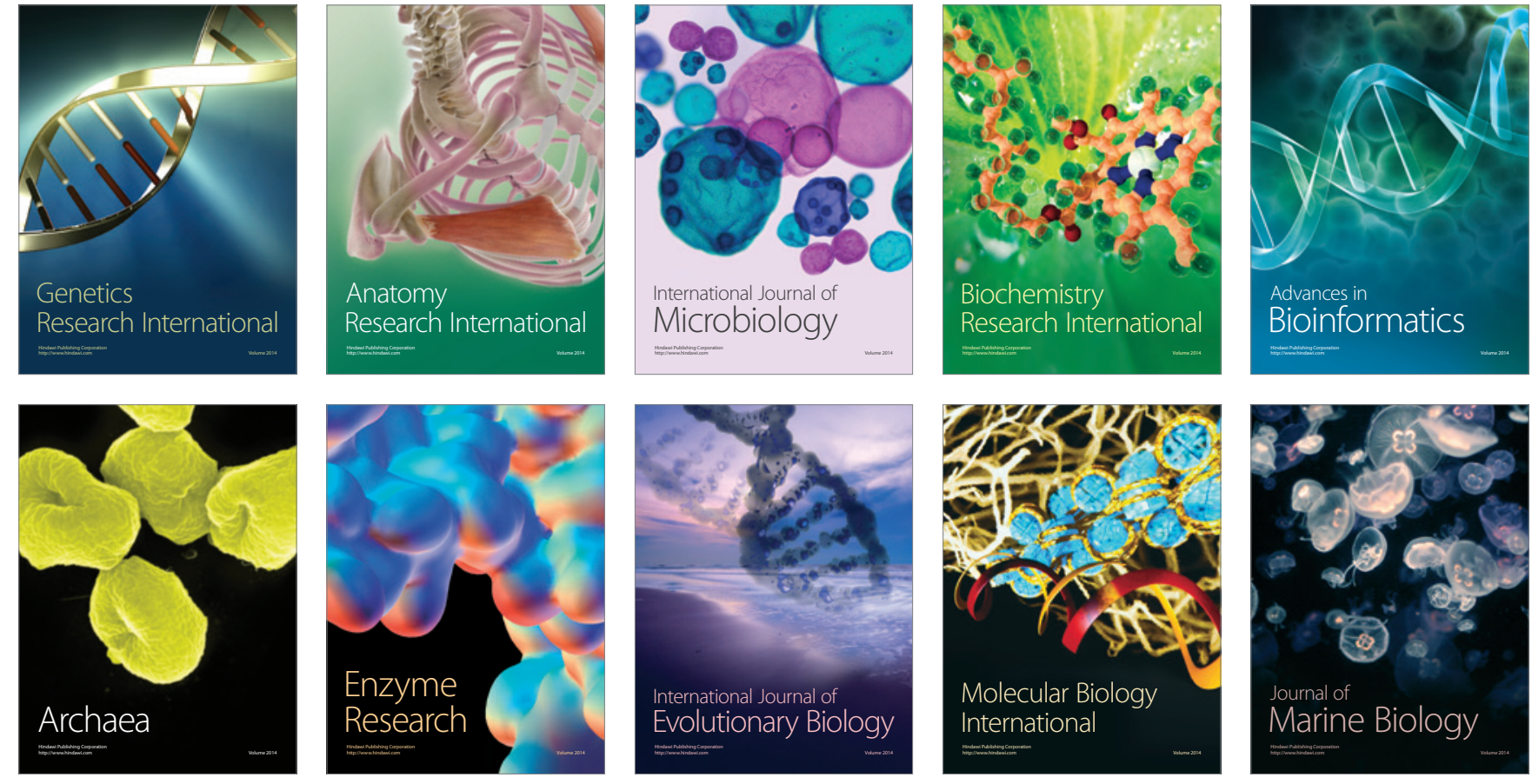